\title{
Educational Design for Alpha Generation in the Industrial Age 4.0
}

\author{
Mir'atun Nur Arifah \\ Department of Islamic Education \\ Islamic University of Indonesia \\ Yogyakarta, Indonesia \\ miratunnurarifah@uii.ac.id
}

\author{
Moch Agus Munir \\ Educational Institution Al-Futuhiyyah \\ Wonosobo \\ Wonosobo, Indonesia
}

\author{
Burhan Nudin \\ Department of Islamic Education \\ Islamic University of Indonesia \\ Yogyakarta, Indonesia
}

\begin{abstract}
Education as an institution for the formation of human resources, has a main task as the transmission of sciences and knowledge, the formation of human character and personality as well as reproduction (candidates) generation. In its development education has been faced with the challenges of changing times and the character of the generation that lives in the present. Therefore, education is expected to be able to transform itself into changes that continue to occur. This study is descriptive-explorative that analyzes the challenges of educational institutions in aspects of educational goals, the direction of the educational process in the future, and the results of educational institutions in the fourth industrial revolution era (RI 4.0). Moreover, the presence of human resources in educational institutions in the future comes from the alpha generation. The generation of Alpha, which is the term for generations born between 2010 and above, has the characteristics of a digital native. The results in this study are the educational efforts of related educational institutions regarding the purpose, content / material of education, and educational approaches to deal with the industrial revolution 4.0.
\end{abstract}

Keywords- Education, Alpha Generation, Industrial Revolution 4.0.

\section{INTRODUCTION}

Educational studies are an endless study. The dynamic of education makes it able to influence and be influenced by various fields in life. One aspect related to the development of education is the development of science and technology. The development of education and the development of science and technology are two things that cannot be separated and influence each other. Renewal of education will bring new knowledge and technology. While the progress of science and technology demands the development of education. This also applies to Islamic education which specifically equips students with Islamic values.

In its journey, education in Indonesia experienced a significant development. This can be observed from curriculum changes that have occurred several times in the world of Indonesian education. Since Indonesian independence in 1945, the national education curriculum has undergone many changes, namely in 1947, 1952, 1964, 1968, 1975, 1984, 1994, and 2004, 2006 and the latest is the 2013 curriculum. These changes are a logical consequence of changes in the political, socio-cultural, economic and science and technology systems in a nation and state society. From these changes it can be seen that the world of education in Indonesia continues to try to adjust to the times. Adjustments are made by redesigning the subject matter and embedding various character values in students.
The world of education in Indonesia is currently faced with the era of distortion which is one of the effects of the 4.0 industrial revolution. This fourth industrial revolution follows massive changes in various sectors. Education is one of the keys in facing the 4.0 industrial revolution. Education is expected to be able to prepare competitive human resources while maintaining national character and culture. The problem faced by the world of education is actually not just how to prepare for the changes that occur due to the industrial revolution 4.0. The characteristics of the young generation who are students at various levels of education in Indonesia must also be considered. The young generation, also known as the millennial generation, has a different character from previous generations. They were born and grew up during the rapid development of technology. Because that's why since childhood, even since birth they have been used to interacting with cyberspace and the ease of existing technology.

These facts attracted the attention of researchers to examine further how to design education that is suitable for millennial generations to become a competitive generation. The millennial generation studied in this study focuses on the generation of alpha which is the most recent generation in the classification of existing generations. While the competition faced is competition in the era of industrial revolution 4.0. so in other words this study aims to explore how education design for alpha generation in the era of industrial revolution 4.0.

The last few years of research related to alpha generation and industrial revolution 4.0 have been carried out several times. These studies examine the generation of alpha and industrial revolution 4.0 from various fields, for example, from the fields of technology, economics, psychology, and so on. But research that addresses these two phenomena and associates them with the field of education is still not widely done, although some have already started it. Research related to this study include the research conducted by Erfan Gazali with the title "Islamic Boarding Schools Among the Alpha Generation and the Challenges of the Educational World in the Era of the Industrial Revolution 4.0". Gazali conducted his research by focusing on the function of Islamic boarding schools as a religion-based educational institution that was faced with the changing times and character of the generation that exists today. His research combines the generation categorization theory by Bencsik, Juhász, \& Horváth-Csikós (2016), the industrial revolution by Schwab, K. (2016, iscoop. (2018) and pesantren studies by (Azra and Jamhari 2006; Ahmad, 2010) The results of his research state that pesantren should be able to integrate changes that occur due to the development of the era while preserving their identity 
as guardians of classical scientific traditions, so that later they can develop the ability of students to be more critical and creative, but not completely dissolved in modernity. This research is more focused on the design of education design that is right for the generation of negatives in the industrial era 4.0. The design of educational design can be used in various forms of formal and non-formal education, so that later this research can complement the research conducted by Erfan Gazali in the design aspects of education that are right for you good Islamic boarding school-based education.

Other research is research conducted by Anju Nofarof Hasudunga, Yusuf Kurniawan entitled "Increasing Awareness of Indonesian Gold Generation in the Face of the Age of Industrial Revolution 4.0 Through Digital Innovation Platform www.indonesia2045.org". This study examines the utilization of the www.indonesia 2045.org platform by the generation of gold described as a group of adolescents and children born in the period 1995-2014. The results of his research are the innovation platform www.indonesia2045.org designed to raise awareness of Indonesia's Golden Generation in the face of the Era of Industrial Revolution 4.0. So that it is hoped that the opportunities obtained in the 4.0 industrial revolution era can bring Indonesia to be the number 4 economic power in the world. The similarity with this research is an effort to prepare the younger generation who are termed the generation of gold or who are also included in Indonesia's alpha generation criteria for the challenges and changes that occur, namely changes brought about by the 4.0 industrial revolution. The difference is the strategy used in this effort. This research uses a strategy by redesigning several important components in the field of education so that it fits the characteristics of today's generation. Whereas previous research uses digital product development strategies that can be accessed by millennial generations.

\section{Methodology}

This research is library research or literature review. Library research is a series of studies relating to library data collection methods, or research whose research objects are explored through various library information (books, encyclopedias, scientific journals, newspapers, magazines and documents). This research is also included in descriptive or taxonomic research. Descriptive research is intended to explore and clarify a phenomenon or social reality, by describing a number of variables relating to the problem and the unit under study. The character of this study is descriptive analytical approached from education. Researchers try to dig up data, analyze, and examine the phenomena that are currently occurring, namely related to alpha generation and industrial revolution 4.0 with the viewpoint of the concept of education science.

This study uses secondary data obtained not from direct observation. The researcher collected data obtained from previous studies that examined alpha generation, industrial revolution 4.0, and educational design. The data collected is sourced from print media such as printed books and journals, or non-printed media in the form of journals that can be accessed by the internet. In addition, researchers also use other sources that come from articles or news online by considering credible sources.

The documentation method is used to collect data in this study. This method is a method of collecting data by searching or digging data from the literature related to the research formula. Researchers collected literature related to alpha generation, industrial revolution 4.0, and educational design and then documented it into a single topic of discussion. The data documentation was then analyzed using the Miles and Huuberman model analysis. The stages of analysis are carried out by reducing the data obtained from each literature. Reduction is done by making a summary to separate the related data. The next step is to display data in a neat and systematic manner that focuses on how to design the right education for alpha generation in the era of industrial revolution 4.0. The last stage is verification of data carried out by making conclusions from existing data and supplemented with other supporting data.

\section{DISCUSSION}

\section{A. Alpha Generation and Industrial Age 4.0.}

\section{1) Definition of Alpha Generation}

The term generation can be used to classify people based on certain criteria. This group can be identified based on the year of birth, age, location, and important events that affect his life. Each generation generally has the same characteristics because they live in the same era, although there are several other things that influence a person's character. Bencsik, Juhász, \& Horváth-Csikós is one that classifies a group of people according to the year of birth. They classify human age into 6 generations. But there are also those who classify generations into more groups because they take a longer age range.

Table 1. Generation Classification Table

\begin{tabular}{|l|l|l|l|l|}
\hline Generation Name & $\begin{array}{l}\text { Births } \\
\text { Start }\end{array}$ & $\begin{array}{l}\text { Births } \\
\text { End }\end{array}$ & $\begin{array}{l}\text { Youngest } \\
\text { Age } \\
\text { Today* }\end{array}$ & $\begin{array}{l}\text { Oldest } \\
\text { Age } \\
\text { Today* }\end{array}$ \\
\hline $\begin{array}{l}\text { The Lost Generation } \\
\text { The Generation of 1914 }\end{array}$ & 1890 & 1915 & 103 & 128 \\
\hline $\begin{array}{l}\text { The Interbellum } \\
\text { Generation }\end{array}$ & 1901 & 1913 & 105 & 117 \\
\hline The Greatest Generation & 1910 & 1924 & 94 & 108 \\
\hline The Silent Generation & 1925 & 1945 & 73 & 93 \\
\hline Baby Boomer Generation & 1946 & 1964 & 54 & 72 \\
\hline Generation X (Baby Bust) & 1965 & 1979 & 39 & 53 \\
\hline Xennials & 1975 & 1985 & 33 & 43 \\
\hline $\begin{array}{l}\text { Millennials } \\
\text { Generation Y, Gen Next }\end{array}$ & 1980 & 1994 & 24 & 38 \\
\hline iGen / Gen Z & 1995 & 2012 & 6 & 23 \\
\hline Gen Alpha & 2013 & 2025 & 1 & 5 \\
\hline
\end{tabular}

From the classification shown in the table, alpha generation is a generation born from 2013 to 2025. But according to Augusto in Erfan Gazali alpha generation is a classification for generations born in 2010 and after. This generation of alpha will dominate the number of people on earth and the number will continue to grow over time. The development of a significant number of alpha generations will bring up a window of demography. It can have an impact on one of two possibilities, namely bonus demography (demography dividend) or even as a curse of demography (demography diases). 
Naming the alpha generation does not continue naming the previous generation, namely generation $\mathrm{X}, \mathrm{Y}, \mathrm{Z}$, because it shows the beginning of new nomenclature for a completely new generation in this millennial era. However, there are also those who think that naming this generation is based more on marketing purposes. Based on the fact that the Alpha generation is basically a Gen Z 2.0 that is not far from its predecessor, it only continues their "legacy". That's why alpha generation actually has similarities with the two previous generations, namely generation $\mathrm{Y}$ and $\mathrm{Z}$ in terms of interaction with the digital world and the internet in life. So that these three generations can actually be classified into one generation group called the digital generation. But all three have differences in the first moment of interacting with the internet and technology. Generation Y knows the internet in their teens and early adulthood, the $\mathrm{Z}$ generation knows the internet at the age of children, while the alpha generation is born in the world with rapid technological development.

\section{2) Characteristics of Alpha Generation}

As the newest generation, Generation Alpha has a character as a generation that grows in rapid technological development. Alpha generation characteristics include

a) Grow and interact with a variety of artificial intelligence technologies (artifical intelligence).

The existence of artificial intelligence technology allows a machine to perform tasks like humans. The trick is to provide the machine with information related to the world so that it is able to learn from experience. This is what makes interaction with the machine feel like interaction with other people because he understands what we need. Ease can also be felt when using a machine with artificial intelligence technology. For example, if you want to shop, someone no longer needs to go to the store because everything he needs can be bought through e-commerce, which can be accessed via smart phone. But the rapid development of technology has also had a negative impact. For example, making someone engrossed in themselves and having difficulty interacting with others.

b) Dealing with digital literacy as a logical consequence of the massive development of information and communication technology

Several studies have been conducted which conclude that millennial generation (including alpha generation) is a generation that is difficult in daily life regardless of smartphone. They tend to change oral communication habits into written communication by using cellphones. So that social interaction that used to be done face-to-face directly, turned into interaction through the internet network. That's why Alpha Generation can also be said as the generation that understands technology most and doesn't know the world without social networking.

c) The ability to filter out the information of the low millennial generation makes them easily provoked by content that contains hatred.

The rapid development of social media makes it easy for humans to find and share information with other parties. Almost all information needed by someone can be known through cyberspace. But the amount of information and convenience to get it does not always have a positive impact. Some individuals use these advantages as a gap to spread negative content. So if there is content that is not in accordance with their thinking, it will be easy to trigger a virtual debate that never ends. When viewed from cultivation theory, it can be seen how the effects of social media can influence audiences to have the view that what they believe happens on the internet or social media is really happening in the real world. So that people who believe it will apply it in their daily lives.

d) Many are influenced by their parents who are generation $X$ and generation $Y$.

Alpha generation is a generation born from the previous millennial generation, namely Gen X or Gen Y. Because of that technology development has influenced the second generation of millennials more or less. Parents from the millennial generation more easily access information from cyberspace so that their knowledge is also broader. The education level of parents of the millennial generation is also much better than the previous generation because access to education is easier. With more modern parenting, the millennial generation tends to prepare their children (generation alpha) with good education so that later they become a more educated generation ready to face big challenges.

\section{3) Industrial Age 4.0}

The concept of the Industrial Revolution 4.0 was first conceived by Prof. Klaus Schwab through his book entitled "The Fourth Industrial Revolution". Schwab is a German economist who is also the founder and executive chairman of the World Economic Forum (WEF). The Industrial Revolution has been going on for 4 periods, since the first Industrial Revolution in the 18th century. Every industrial revolution that occurs, has its own characteristics in accordance with the development of its era. This fourth industrial revolution is considered to have a wider scale, scope and complexity than the previous industrial revolution. This is due to new technological advances integrating the physical, digital and biological worlds that have influenced all scientific, economic, industrial and government disciplines. As a result the fourth industrial revolution has a massive impact on human life in the world. This impact is also influenced by the birth of digital technology that drives automation systems in various activities.

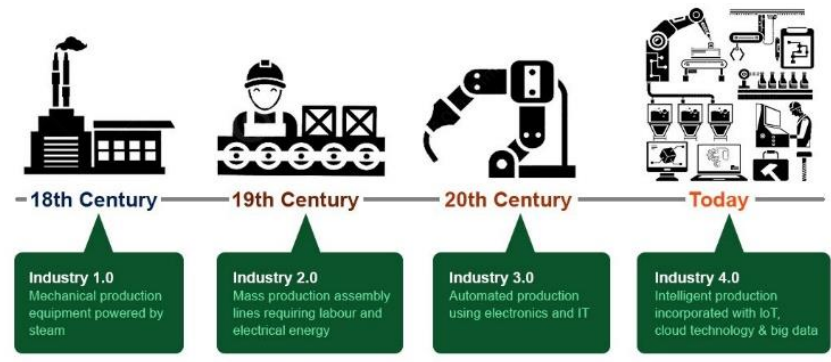

Figure 1. Industrial Revolution from time to time

Industrial Revolution 4.0 is supported by advanced technology in the form of artificial intelligence, robotics, virtual reality, and three-dimensional printing machines. The consequences of using these advanced technologies have resulted in the possibility of losing some types of work. However, the use of advanced technology is also able to bring up jobs that have never been before. So that in other words there is a change in the type of work, even though with the 
presence of robots and sophisticated machines still make jobs less and less.

RI 4.0 has created a phenomenon in the business world which is called disruptive innovation, which is an innovation that creates a new trend and industrial network. The business world is so dynamic that it is able to change previously existing patterns into more innovative new business patterns. This means that these changes occur fundamentally and massively. The impact of this phenomenon can be felt by all levels of society because it covers a variety of fields, ranging from transportation, communication, to education. For example, in terms of education, nowadays someone can learn not only in school and with educators. But he can study anytime and anywhere by accessing educational sites through his smartphone or computer.

\section{4) Characteristics of Industrial Era 4.0.}

Some of the characteristics of the industrial era 4.0 that distinguish it from previous eras, among them are

\section{a) Robotic Automation}

Robots are one of the works formed because of the development of science and technology. Currently the use of robots in various fields of life is something that usually happens. Various types of robots are made to facilitate human work, so it is not surprising that later human work will be taken over by robots because they are considered more effective and efficient. This implies that in the future, competition in employment is not only between humans but also with sophisticated machines. That's why labor in all fields in the era of Industrial Revolution 4.0 is required to have various skills as more value. Among the skills needed are digital skills, both technical and managerial workforce and social skills.

\section{b) Internet of Things and Data of Things}

The internet of things and data of things are two things that are interrelated. Both emphasize the integration between tools using the internet and the use of big data. According to Casagras (Coordinator and support action for global RFIDrelated activities and standardization) defines the Internet of Things as a global network infrastructure, which connects physical and virtual objects through the exploitation of data capture and communication capabilities. Internet of things allows everything in life to be connected to the internet. For example, through applications that are made to facilitate work and human activities. This certainly provides benefits because the process is more efficient because of the optimization of speed, optimization of adaptability, and optimization of reliability. While the data of things is the result of collecting data obtained from internet users that can be utilized in various fields. These data allow machines to recognize and identify someone through activities they have done in cyberspace. However, this has shortcomings in data security and someone's privacy.

\section{B. Problems with education in the Industrial Age 4.0.}

Education in its history has always been a conversation ranging from the lower (community) to the upper class (government, education experts). Especially at this time the world is heading to the gate to enter the era of industrial revolution 4.0. Education was again rocked and demanded to be able to adjust to that era. First, education is required to create human resources that not only rely on technical capabilities, but human resources that are creative, innovative and transformative. Second, the educational process does not only focus on what is taught, but also the way of teaching in which education itself is based on the need to meet existing needs in the future. It has become common consumption that education is now seen as a lifelong process not just as a stepping stone towards the professional world. Education 4.0 is considered as an opportunity for schools that are ready to foster the readiness of their students to enter a new phase of the education world that has changed so rapidly.

Both of these educational adjustments can be carried out if the education sector can solve classical problems which until now are still often discussed by education experts. These problems include:

\section{1) Educational Objectives}

The Indonesian government has sought the development of the education sector, through the 9-year WAJAR (compulsory education) policy, or even in certain regions it has been compelled to REQUEST 12 years. This policy, is expected to be able to provide education services in Indonesia that are equitable and proportional for the creation of educated human resources. Furthermore, the Indonesian government is pursuing educational goals that can provide opportunities for the community through the provision of student education, the bidik misi program in higher education, and others. The community does not remain silent. Many community institutions also participated in increasing this education participation rate. The increase in quantity in attending education has not been followed by a description of the appropriate educational outcomes. With the increasingly educated community, it is hoped that civil society will be created and have a high level of civilization and be able to have high competitiveness. Educated people should emphasize more on the use of rationalization or common sense in solving problems faced in social life.

But what happens now is not the case. Corrupt behavior, brawl, hedonism lifestyle, fast despair, selfishness, lack of confidence, narcotics abuse and the habit of cheating or plagiarism among students are examples of widespread public behavior today. These phenomena are a picture that is not in line with the expectations of educational outcomes. The condition of the quality of human resources (HR) as above causes the level of competitiveness of the Indonesian people at the world level is relatively low. The Global Competitiveness Report 2017 (annual report on global competitiveness in 2017) made by the World Economic Forum (WEF) places Indonesia in 36th position out of 142 countries in the world. In the ASEAN region Indonesia's competitiveness position is fourth under Singapore, Malaysia and Thailand.

All problems lie in the orientation or purpose of education which is still limited to cognitive-learning. The problem of the purpose of education seems to emphasize the accumulation of verbal knowledge rather than the mastery of skills, the internalization of values and attitudes, and the formation of personality. Besides that the quantity seems to take precedence over quality. The percentage or number of graduates is preferred over what is mastered or can be done by these graduates. Education in Indonesia has been aimed at guiding and developing potentials in students. This goal is a general conception that exists in education everywhere, but 
there are specific objectives that should be developed in accordance with the conditions of the times that are always developing towards the future.

This particular goal is adaptive and transformative. Meaning is the ability to formulate for the purposes of dynamic conditions and conditions. But the problems that occur in the body of education cannot be solved. The specific purpose of education is always oriented towards fulfilling knowledge in the human brain (transfer of knowledge). The more students absorb the contents of education, the better in following the education process. The conception of this goal has many fundamental weaknesses, namely, (1) the goal is still based on cognitive knowledge, which is static rather than dynamic (2) the opportunity of students to develop knowledge only rests on the ability to "know" and "understand", not " explore "and" collaborate ". (3) the fulfillment of knowledge will only lead to thinking in the child into one direction "one view".

\section{2) Educational Content / Material}

The world has entered the industrial era 4.0. but the problem of education in Indonesia is still the same, namely, the education curriculum. The problem is divided into two, First, the overly complex curriculum is based on the fulfillment of knowledge in students. This results in educators and students. Students are burdened with a myriad of material they must master. Students must strive to understand and pursue targeted material. This results in students not understanding all the material being taught and preferring to study the material and only understand the material in passing. The impact is that students' knowledge is reduced and less focused in exploring scientific fields, and less responsive in facing increasingly global competition. In addition to having an impact on students, educators also have an impact. The task of the educator is increasingly piling up and not maximal in providing teaching. Educators are burdened with achieving too many material targets, even though there are still many students who experience difficulties, educators must continue the material. This is not in accordance with the role of educators.

Secondly, besides that, the curriculum in Indonesia often changes. However, these changes are limited to changes in curriculum identity alone. Without changing the curriculum concept, there is certainly no positive impact from changes in the Indonesian curriculum. In fact, changing the curriculum can be used as business land by irresponsible individuals. Changing the curriculum certainly requires a lot of funds. If viewed from an economic point of view, it would be nice if the funds were used for educational assistance that had more potential for the advancement of education.

These problems generally hamper students to release their potential and talents. This is because students tend to be afraid of educators because of the introduction of a brief glance at the material without having to develop material (passively). Students are only fixated on the material taught by educators without any sense of wanting to try to develop their potential

\section{3) Educational Methods and Approaches}

In the process of teaching and learning in schools conducted by educators of certain subjects experience various kinds of obstacles faced. These problems hit students and educators, which in turn caused the teaching and learning process not conducive. In addition to not being conducive to the atmosphere during the learning process, it also results in difficulties for students in capturing / receiving material provided by study educators. When students are not able to receive the material conveyed by educators, then at the time of evaluation students feel difficulty working on the problem. Therefore the goals to be achieved from teaching and learning activities in related subjects cannot be achieved. And all the efforts made by educators and students cannot be maximally the results can even fail. Problems that occur in teaching and learning activities some of which are:

a) The lack of competence of educators in certain fields of study

b) The lack of ability of educators in understanding the character of each student

c) Inability of study educators to choose the right learning method in the teaching and learning process

d) The lack of educator creativity in presenting subject matter

Actually there are still many problems that occur in teaching and learning activities between students and educators. At the heart of these problems is the occurrence of missed understanding or missed communication between the two parties, which ultimately has fatal consequences. I want to look at the application of learning methods that are not appropriate for students. Actually the failure of the method used by educators is related to almost all the problems that exist in teaching and learning activities.

In addition to the above reasons there is also a problem, namely a system of institutions created by humans or related educational institutions. With reasons to discipline educators and students and facilitate the achievement of targets or learning goals. Actually it is good to procure the system, but sometimes even this system is used to benefit one party only. The advantage of the dominant party results in the death of freedom in teaching and learning, and violating human rights. Finally educators are sometimes not right in choosing the method maybe only by giving assignments and very irrelevant methods. Actually, the system is good because it helps humans in activities, but when a system that becomes a human regulator and the system does not humanize humans, it will inhibit that human being. The application of the system is mandatory but must humanize humans and must also consider all human perspectives and not inhibit human beings in facilitating the selection of learning methods.

\section{INDUSTRY ERA 4.0 EDUCATION DESIGN}

\section{A. Skill Based Education}

Skill-based education is a strategy to maximize the success process in the era of Indonesian 4.0. In the industrial era 4.0 which incidentally as a phase of technological revolution changed the way human activities in scale, scope, complexity, and transformation from previous life experiences. Humans are in the dimension of global uncertainty, therefore humans must have the ability and skills in order to predict a rapidly changing future. Indonesia is also predicted to experience a demographic bonus in the years 2030-2040, which in that year was a golden year for the alpha generation. The demographic bonus has an important point, namely, the population with more productive age compared to the non-productive population. The population of productive age is estimated to 
reach $64 \%$ of the total population of Indonesia which is estimated at 297 million. Therefore, the number of people with productive age must be followed by quality improvement, both in terms of education, skills, and the ability to compete in the labor market. For this reason, skills-based education is needed, so that generation alpha can be educated in accordance with the times and challenges.

In the future, alpha generation is the generation with the most dense growth and development rates compared to the next generation. The birth of the alpha generation of children born to millennial and generation $\mathrm{Z}$ generations. Where both generations live and develop in the technological age, so the alpha generation is the real generation that lives from the womb to birth surrounded by various technologies and digital, as well as Artificial Intelligence (artificial intelligence) and robots that are like humans. They live and enjoy all kinds of games that are directly connected and will respond to commands and be able to show emotional intelligence. Seeing the significant growth in the Alpha generation, it is not impossible that this generation has become the generation that has the most number ever. It is estimated that the number of alpha generations born every week is 2.5 million, so that by 2025 the number will swell to around 2 billion by 2025 (Williams, 2015). According to Kartadinata (2018) the number of digital generations who like to interact on the internet in Indonesia reaches 54 percent, Asia as much as 55 percent. They feel something is lacking without social media. The generation that experienced this kind of thing in Indonesia reached 69 percent, Asia as much as 46 percent. Being a generation educator who is very familiar with technology with abundant information is not an easy thing.

There are a number of things that need to be prepared by educators and educational institutions in preparing education systems for this generation. According to Zmuda, Alcock, \& Fisher (2017), there are four things that need to be prepared by educators before students from the alpha generation enter their learning space namely, First, Focus on skills, not content (Focus on skills, not content), second, Providing learning with greater flexibility and goals (Provide learning with flexibility and a greater purpose); third, planning for collaborative capacity building (Plan for collaboration); fourth, developing soft skills (Cultivate soft skills). The principles that must be implemented by educational institutions to prepare alpha generation in the industrial era 4.0 as follows:

\section{1) Education Rests on Innovation and Creativity}

Educational institutions in the Millennium era and globalization like now have made a lot of climate in educational institutions that teach their students to create knowledge, and not only eat raw and complete knowledge. This means that these educational institutions can create an intellectual climate and be adapted to the development of their students. McLoughlin and Lee argue that the ultimate goal of learning is to stimulate the ability of students to compile and produce ideas, concepts and knowledge. This goal can be achieved if the needs are met for meaningful learning experiences that utilize and develop students' creativity, and not turn it off. Educators can play a key role by encouraging, identifying and developing students' creativity. However, teaching creativity such as teaching all knowledge requires environment and devices that can support the development of creativity. What's more, alpha generation is a generation that will be interested in authenticity and reject subject matter that is separate from the context they experience. They want to create valuable products that allow them to integrate the material they learn with the experience of their knowledge and show what they know in a non-traditional way. Educators need to consider learning outcomes that enable students to show what they know and be able to do in innovative and creative ways in various fields of material and share these creations with virtual communities both locally and globally.

Therefore, future learning projects are mainly intended to respond to the revitalization of industry 4.0 in the alpha generation, should use a student centered approach. Students as subjects of learning who actively develop their interests and potential to create their own innovation and creativity. Conventional learning such as students is not required to memorize the subject matter given by educators, but constructs their knowledge and skills, according to their capacity and level of development of thinking, and are invited to contribute to solving real problems that occur in society. This does not mean that educators give up control of learning to students fully, but educator intervention is still needed. Educators act as facilitators who try to help link the initial knowledge (prior knowledge) that students already have with the new information they will learn, give students the opportunity to learn according to their own learning styles and ways, and encourage students to take responsibility for the learning process that he does. Educators also act as mentors, who strive to help students when finding difficulties in the process of constructing their knowledge and skills.

\section{2) Open Education Against the Outside World} (Flexibility)

The industrial revolution 4.0 opened the outside world as widely and as widely as possible. The world becomes a "small village", in which there are no more boundaries and spaces to be isolated. The present era is very easy to connect with, not only about communication, friendship, and economics, but also other dimensions of life. Especially for the alpha generation born in the massive technology and digitalization era, there needs to be an educational pattern that is open to all the information and culture it carries. This is where the role of educational institutions can prepare new villages in education, so that the alpha generation can develop optimally.

Desaign is one of them is flexibility context learning, namely, flexible and dynamic learning that is able to accommodate knowledge in accordance with the abilities and skills possessed by students without being shackled by methods, approaches, material and restraining evaluation. In various forms of open and long distance education, students can carry out daily activities for the sake of the continuity of life or institutional mission. The students are able to learn on the sidelines of the activity with self-learning materials that are deliberately developed for that purpose. When there are problems in learning that they cannot solve on their own, they can seek help from a resource person who is nearby or who is given the task of guiding. For both administrators and the community, open and distance education also brings benefits, for example: (1) business can be accelerated to meet the needs of the community and the job market; (2) can attract many prospective participants; (3) the disruption of daily life activities due to flexible learning patterns and schedules; expectations for increased cooperation and graduate user support or output. Furthermore, in this principle, education must also emphasize the global aspects of pedagogy, not 
cultural pedagogy, but it will make the material taught by the instructor able to be well received by heterogeneous students, not homogeneous. High creativity is demanded as well as a large inobative spirit to be able to produce a quality and acceptable learning quality towards the mulicultural audience.

\section{B. Digitizing Learning}

Learning is the primary process in implementing education. One of the goals of learning is how to regulate information and the knowledge environment so that students can learn well. Learning not only prepares a place for learning, but learning exceeds that, that is, includes the arrangement of methods, media, and various equipment needed to convey information and membinbing students to learn. Smaldino explained that learning is a variety of efforts carried out to stimulate learning by managing experiences to help students achieve meaningful changes in abilities. Learning includes all events and activities that affect the learning process of students. In accordance with the development of information technology today, learning is not only limited to classrooms in schools, but can also be in the form of computer-assisted learning and web-based learning. Thus, learning is a process that includes the selection, arrangement, and delivery of information in the appropriate environment and how individuals interact with that information.

Learning in the 21 st century or more, especially in the industrial era, is more oriented towards digital lifestyles, thinking tools, learning research and how knowledge works. The orientation of learning is very close to skills and vocational education, namely how to work knowledge, strengthening thinking tools, and digital lifestyle. The workings of knowledge are the ability to collaborate on teams with different locations and with different tools, strengthening thinking tools is the ability to use technology, digital tools, and services, and digital lifestyle is the ability to use and adapt to the digital era.

The Indonesian government seems to have prepared learning strategies in the industrial era 4.0. This was conveyed through the Minister of Trade of the Republic of Indonesia who had compiled four strategies to face the challenges of the Industrial Revolution 4.0. First, it encourages the workforce in Indonesia to continue to learn and improve their skills to integrate internet capabilities with production lines in the industry. Second, the use of digital technology to spur productivity and competitiveness for small and medium industries so as to be able to penetrate the export market through e-smartIKM programs. Third, using digital technology such as Big Data, Autonomous Robots, Cybersecurity, Cloud, and Augmented Reality. Fourth, technological innovation through the development of startups by facilitating business incubation.

In line with what was conveyed by the Director General of Resources of Science, Technology and Higher Education, Prof. Dr. Ali Ghufron Mukti, MSc. Ph.D. emphasize if learning in the Industrial Revolution era 4.0 is grouped into three models, namely: conventional face-to-face models; online and automation models; and blended learning models. Of the three learning models presented, as a solution, the most appropriate and adapted to the times, educational institutions need to establish a blended learning learning model. The blended learning model combines online (digital) learning and face-to-face learning in classrooms or in the laboratory. The blended learning model is an innovative effort that combines the advantages of classroom learning (offline) and online. When the term blended becomes popular, more and more combinations are referred to as blended learning. In research methodology, mixing terms are used to show a combination of quantitative and qualitative research. There are also those who call in learning an eclectic approach, namely combining various approaches to learning. However, the notion of blended learning based learning is learning that combines the strategies of delivering learning using face-to-face activities, computer-based learning (offline), and online computers (internet and mobile learning).

Digital-based learning or the internet has several advantages, namely: internet browser software can be used freely, has multi-platform capabilities, can update content and structure easily and quickly, shifting from programming costs to structural design and content costs, faster in completing products, not many need technical support, can control access, and can be used for distance learning. Digital based learning can have a positive impact on students if the learning strategies used support other learning components, in accordance with learning outcomes, facilitate self-directed and collaborative learning, and provide practical activities and feedback. In addition, the digital learning model can develop cognitive, psychomotor, and interpersonal skills. Digital based learning has been proven to have high dynamics and in accordance with the era of industrial revolution 4.0. Adapting to the Industrial Revolution 4.0 it is time to develop digitalbased learning by educational institutions, because there are already available internet technology facilities in schools and in higher education.

Blended learning in addition to the use of digital based learning also collaborates with face to face learning. This conventional learning is specifically related to the direct experience of students in enjoying the learning process. This learning is referred to as experiential learning developed by David A. Kolb in 1984. Experiential learning is a process in which knowledge is created through the transformation of experience. A person's knowledge results from a combination of transformation and mastery of experience. The same opinion was expressed by Siberman that Experiential learning implies the involvement of students in real activities that make them experience what they are learning, and the opportunity to reflect on these activities. Experiential learning can be done in the form of real work, or it can be in the form of structured experience that is in accordance with the real work. The Association for Experiential Education provides a definition of experiential learning as a process by which students construct knowledge, skills and values from direct experience. Based on these theories, it can be concluded that experiential learning is a learning strategy that involves students in real experiences in order to construct knowledge, skills and attitudes.

Suggestions for instructors who will use digital should be implemented in blended learning. Collaboration or collaboration is one of the important features of future learning that prioritizes individual abilities, but this ability is then synergized to produce products, because of future products, especially computer products in the form of complex hardware and software, an interdisciplinary approach is needed. Therefore future products are products that result from collaborative activities. Collaborative skills must be an 
important part of blended learning based learning. This is certainly different from conventional face-to-face learning, where all students learn in the same class under the control of the teacher, in blended based learning, students work independently and collaborate.

Evaluation of blended learning based learning will certainly be very different compared to the evaluation of faceto-face learning. Evaluation must be based on the process and results that can be done through an evaluation of teaching and learning performance based on the portfolio. Likewise, the assessment needs to involve not only the teaching authority, but also the self-assessment of the students, as well as other student assessors.

\section{CONCLUSION}

In conclusion, to prepare Indonesia's young generation as the nation's next generation, education needs to be designed in such a way as to fit the characteristics of the generation and in accordance with the times. The generation in question is the alpha generation which will dominate the population in Indonesia as a bonus demographic. Educational design is also adapted to the development of the industrial revolution 4.0 that will be faced by that generation. Educational design offered from the results of this study include skills-based education and learning digitalization. Skills-based education can be realized in the form of education that is based on innovation and creativity and education that is open to the outside world. Both educational designs are designed taking into account the various characteristics of alpha generation and the characteristics of the 4.0 industrial revolution so as to be able to contribute to the development of Islamic education.

\section{REFERENCES}

[1] Adam Nagy and Attila Kolcsey 2017 Generation Alpha: Marketing or Science? Acta Technologica Dubnicae Vol 7 Issue 1 DOI: 10.1515/atd-2017-0007

[2] Alhamduddin 2014 Sejarah Kurikulum Di Indonesia: Studi Analisis Kebijakan Pengembangan Kurikulum Jurnal Nur El Islam Vol 1 No 2

[3] Alisson Zmuda Marie Alcock Michael Fisher Meet Generation Alpha: Teaching the Newest Generation of Students accessed from https://www.solutiontree.com/blog/teaching-generation-alpha/

[4] Alex William https://www.nytimes.com/2015/09/19/fashion/meetalpha-the-next-next-generation.html

[5] Anju Nofarof Hasudungan, Yusuf Kurniawan 2018 Meningkatkan Kesadaran Generasi Emas Indonesia Dalam Menghadapi Era Revolusi Industri 4.0 Melalui Inovasi Digital Platform www.indonesia2045.org Seminar Nasional Multidisiplin UNWAHA Jombang ISSN : 2654-3184

[6] A Malik Fadjar 1998 Visi Pembaharuan Pendidikan Islam (Jakarta: LP3NI)

[7] Bernie Trilling \& Charles Fadel 2009 21 st Century Skills: Learning for Life in Our Times (San Francisco: Calif., Jossey-Bass/John Wiley \& Sons, Inc)

[8] Catherine McLoughlin \& Mark J W Lee 2008 The three p's of pedagogy for the networked society: personalization, participation, and productivity International Journal of Teaching and Learning in Higher Education Vol 20 N 1Central Statistics Agency "Proyeksi Penduduk Indonesia 2010-2035" https://www.bappenas.go.id/files/5413/9148/4109/Proyeksi_Pendudu k_Indonesia 2010-2035.pdf

[9] Charles Leadbeater 2008 What's Next? 21 Ideas for 21st Century Learning, (London: The Innovation Unit)

[10] Cynthia Luna Scott 2015 The Futures of Learning 3: What kind of pedagogies for the 21st century? UNESCO Education Research and Foresight ERF Working Papers Series No 15
[11] Cynthia Perlman Cynthia Weston Erika Gisel 2005 Web-Based Tutorial To Enhance Student Learning Of Activity Analysis in The Canadian Journal of Occupational Therapy Vol 72 No 3 ProQuest

[12] D P Ausubel 1968 Educational Psychology: A Cognitive View (New York: Holt, Rinehart\& Winston)

[13] David A Kolb 1984 Experiental Learning: Experience As The Source Of Learning And Development (New Jersey: Prentice Hall)

[14] Erfan Gazali 2018 Pesantren Di Antara Generasi Alfa dan Tantangan Dunia Pendidikan Era Revolusi Industri 4.0 OASIS: Jurnal Ilmiah Kajian Islam Vol 2 No 2

[15] Fitri Wahyuni 2015 Kurikulum dari Masa ke Masa: Telaah Atas Pentahapan Kurikulum Pendidikan di Indonesia Jurnal Al-Adabiya Vol 10 No 2

[16] H.A.R. Tilaar 2004 Multikulturalisme: Tantangan-Tantangan Global Masa Depan Dalam Transformasi Pendidikan Nasional (Jakarta: PT Grasindo)

[17] Indonesian Minister of Trade Http://kemenperin.go.id/artikel/17565/Empat-Strategi-IndonesiaMasuk-Revolusi-Industri-Keempat

[18] John Howrey and Kelly Quinn 2016 Assessing Student Attitudes to Moodle versus Print Materials for L2 Vocabulary Acquisition International Journal of Information and Education Technology Vol 6 No 1Khumo Theko http://www.fluxtrends.com/meet-generationalpha/

[19] Lalima and Dangwal 2017 Blended Learning: An Innovative Approach Universal Journal of Educational Research Vol 5 No 1

[20] Malcolm Ronald Pritchard 2010 Experiential learning programs in Australian Secondary Schools in Submitted in total fulfilment of the degree of Doctor of Philosophy (Melbourne Graduate School of Education The University of Melbourne).

[21] Mell Siberman 2007 The Handbook Of Experiental Learning (San Fransisco: Pfeiffer)

[22] Michael T. Robinson, https://www.careerplanner.com/CareerArticles/Generations.cfm

[23] Muhammad Fathi Rauf https://medium.com/@mfrauf/internet-ofthings-iot-dalam-revolusi-industri-4-0-f4d0356d9f42

[24] Nana Syaodih 2009 Metode Penelitian Pendidikan (Bandung : Remaja Rosdakarya)

[25] Noveliyati Sabani 2018 Generasi Milenial dan Absurditas Debat Kusir Virtual Informasi: Kajian Ilmu Komunikasi Vol 48 No 1 doi: h p://dx.doi.org/10.21831/informasi.v48i1. 18078

[26] Republika.co.id

[27] Roni K. Pratama Jassin dan Generasi Milenial accesed from https://geotimes.co.id/opini/jassin-dan-generasi-milenial/

[28] Sanapiah Faisal 1992 Format-Format Penellitian Sosial: Dasar-Dasar dan Aplikasi (Jakarta: CV Rajawali)

[29] Sharon E Smaldino Deborah L Lowther James D Russel 2008 Instructional technology and media for learning (9th ed.) (New Jersey: Pearson Education, Inc)

[30] Slamet Rosyadi https://www.researchgate.net/publication/324220813_REVOLUSI_I NDUSTRI 40

[31] Sue Newell, "Knowledge transfer and learning: problems of knowledge transfer associated with trying to short-circuit the learning cycle" in 2005 JISTEM - Journal of Information Systems and Technology Management Vol 2 No 3

[32] Sudarwan Danim 2006 Agenda Pembaharuan Sistem Pendidikan Cet. Ke-2 (Yogyakarta: Pustaka Pelajar)

[33] Suharsimi Arikunto in Yuni Irawati 2013 Metode Pendidikan Karakter Islami Terhadap Anak Menurut Abdullah Nasih Ulwan dalam Buku Pendidikan anak dalam Islam dan Relevansinya dengan Tujuan Pendidikan Nasional (Sripsi tidak diterbitkan, UIN Sunan Kalijaga)

[34] Sunaryo Kartadinata Tantangan Pendidikan Dalam Era Digital accessed from http://jabarekspres.com/2018/tantangan-pendidikandalam-era-digital/

[35] Sutirman 2018 Inovasi Pembelajaran Kearsipan Digital di Era Revolusi $\begin{array}{llll}\text { Industri } & 4.0 & \text { accesed } & \text { from }\end{array}$ https://www.researchgate.net/publication/327049611

[36] Sutrisno 2013 Upaya Mewujudkan Generasi Emas melalui Kurikulum 2013 Paper presented in National Seminar: Bedah Kurikulum 2013: 
Repositioning Pendidikan Agama Islam (PAI) untuk Mewujudkan Generasi Emas On Saturday, June 15, 2013 Kediri: Program Pascasarjana STAIN Kediri.

[37] Triyono 2016 Menyiapkan Generasi Emas 2045 delivered in National Seminar ALFA-VI, Unwidha Klaten, Acessed form https://www.researchgate.net/publication/324029744
[38] Waled Al-Nuaimy Zhang J \& Noble A 2001 Web-based learning environment for a communications module in Department of Electrical Engineering and Electronics, University of Liverpool, Brownlow Hill, Liverpool L69 3GJ, UK

[39] World Economic Forum; The Global Competitiveness Report 20172018. 